\title{
Degradation, Meaning Shift, and Redefinition of the City Parks' Social Function in the Presence of Virtual Space Facility
}

\section{Handoyotomo', Adiansya Halimawan², Nensi Golda Yuli ${ }^{3}$}

\footnotetext{
1 Architect Professional Education Study Program, Department of Architecture, Faculty of Civil Engineering and Planning, Universitas Islam Indonesia

2 Architecture Master's Study Program, Bandung Institute of Technology, West Java, Indonesia

3 Architecture Master's Study Program, Department of Architecture, Faculty of Civil Engineering and Planning, Universitas Islam Indonesia, Yogyakarta, Indonesia
}

\author{
Article History \\ Received : 15 March 2018 \\ Accepted : 15 March 2018 \\ Published : 01 October 2018
}

\begin{abstract}
As one of the big cities in Indonesia, Bandung has now made many improvements to the city park facilities and infrastructure. The quality improvement can be seen not only in the physical form of various city spaces but also though the free internet access available for park users. This has an impact on the behavior of park users, which slowly affects the dynamics of park activities as well, especially the emergence of virtual space. The presence of virtual space in the city park provides a variety of positive and negative responses in the way people socialize. This paper aims to examine the phenomenon and impacts, the meaning shift, and the redefinition the social functions of urban parks due to the availability of free internet facilities that give rise to virtual spaces in the parks of Bandung. The data were taken from the Superhero Park, Elderly Park, Fitness Park, and Dago Park using structured interviews and observations of visitor activities as the data collection techniques. It is found that the presence of wifi facilities is viewed positively in terms of information access, but is viewed negatively in regard to the essential functions of urban parks which are originally created as a social space. Therefore, the study concludes that there has been a degradation of functions in the urban park facilities, because the nature of virtual space itself tends to bring humans to get carried away in it and interrupt their activities from the space of reality. City parks have also experienced a shift in meaning, thus creating a build-up of space that creates virtual space into the real world in the form of a park.
\end{abstract}

Keywords: City Parks, Virtual Spaces, Social, Bandung

Information Technology as the Cause of Interaction Shift in the Public Space

The increasingly rapid development of information technology has allowed it to be more

Correspondence: Handoyotomo

Architect Professional Education Study Program, Department of Architecture, Universitas Islam Indonesia E-mail: handoyotomo@uii.ac.id accessible to anyone. One of the developments is in the form of the access of wireless internet/ wifi. At the present, most public spaces in big cities in Indonesia have been provided with free wireless internet access. As a part of the city's quality improvement process of infrastructure and facilities, several public spaces in Bandung have made free internet access available, as well. In regard to Bandung's current vision of being a Smart City, the city initiates the Internet for All program in all public spaces all over 
the city with 10,000 free wifi access under the "Bandung Juara" initiative. The internet is provided by various corporations as a part of the corporate social responsibility (CSR) and realized by PT. Telkom (Anindita \& Suwandono, 2015).

A study shows that internet users in public facilities such as city parks generally tend to isolate themselves and become unresponsive to what happens around them (Hampton et al., 2010).

The internet users' unresponsiveness to their surrounding environment in the public facility is caused by the new environment that they are engaged in, bringing them into the digital world (virtual environment). At this point, humans and technology are no longer separable, as the virtual and real world has become indistinguishable and integrated into one. Technology produces virtual space that brings humans along within it, resulting in the interruption of relation with the real world, which soon turn or perhaps have turned humans into zombies who are not aware of their physical reality (Renaningtyas, 2013). The irony lies on the fact that the technology is available for free in the public spaces that are supposed to strengthen the social function, yet in fact is even further away from the essence of the public space with its initial function. This study will discuss to what extent is the meaning shift of city parks as public space in the presence of virtual space facility.

Research data in the form of observed activities of city park users in Bandung were obtained through field survey and observation on the activities of Bandung residents in the four thematic parks in the city, namely Superhero Park, Elderly Park, Fitness Park, and Dago Park. Structured interview was also done on city park visitors to obtain information on their reasons or purposes in visiting the city park and understanding on the city park in the past and at the present.

Analysis will be done based on the perceptions on the use of city parks and activities done during the interview. The conflicts on the implementation of the meaning of public space in the city parks' typology and its significance as the media to enjoy the virtual space will be analyzed in-depth in order to examine the correlation to each other, and investigate whether there is a new meaning in the use of city parks at the present.

\section{Public Space}

Kevin Lynch (1960) explains that public space is an important part of the image of a city (Beqaj, 2016). By definition, public space can be described as a space or area for the public (Ramlee et al, 2015). In the multicultural context, "space" and "public" each has its own definition.

According to regulation applied in Indonesia, public space can be grouped into green open space and non-green open space. Non-green open space is regulated in the Regulation of the Minister of Public Works no.12/2009, and the green open space is regulated in the Regulation of the Minister of Public Works no. $5 / 2008$. Green open space is defined as an elongated area/ lane or cluster, in which the use is open, for plants to grow naturally or planted manually. On the other hand, non-green open space is an open space in the urban area that is not included in the green open space category, in the form of hardened land, a body of water, or certain poreless surface that is uninhabitable for plants (PU, 2009 : 13). Based on the regulation, city parks belong in the scope of urban public space.

In creating a certain space, humans always begin with an idea that there is a specific activity in the space (Rapoport, 1977). Therefore, the human dimension cannot be overlooked in the open space design. The quality of city planning and design for a public space must be based on the following three aspects (Beqaj, 2016): versatility, inclusivity and access, and fairness. In general, public space is instrumental in city development, in regard to the environment, culture, and economy aspects. Public space is a depiction of a life of a community that goes through constant change; on the other hand, public space has been determined as open space, a space accessible for the general public, as well as a place for the public to do personal or group activities.

\section{The Role And Function Of City Parks As A Social Space}

City parks are where humans conduct their activities and engage in social interactions to obtain joy, happiness, and comfort. City parks 
may anticipate the potential impacts of city development and simultaneously be enjoyed by the people of the city (Gallion \& Eisner, 1994; Laurie, 1986).

City parks can also be defined as communal shared space for doing various activities, which is why Carr et al. (1992) classify city parks as a part of public space. This is because public space is the stage in which the play of a community life ensues (Carr et al., 1992).

We are currently entering a new era on defining what a park is, as it is not only seen as a place of trees and greenery. Parks have provided several advantages for the users. They are a breath of fresh air amidst the traffic congestion and populated housing complex. Parks have also developed into recreational center and facilities, as well as played a more integrated role in the city environment (Levitz, 2014).

The main roles of public space, especially city parks, are to serve as the lung of the city, as well as to provide a sense of beauty and balance in the urban life in accordance with its functions as a place for the community to socialize, as well as for health and recreational purposes. There are 11 main roles that parks in the urban area has, namely community revitalization, community engagement, economic development, to create safer neighborhood, green infrastructure, help children learn, improve public health, arts and cultural program, promote tourism, smart growth, and climate change management (American Planning Association (APA), 2017).

On the other hand, there are three main values that a city park must have in order to be a public space with good social space function (Carr et al., 1992), namely responsive, democratic, and meaningful. A responsive space can be defined as a space that provides convenience and relaxation for the users (Rubenstein, 1992) as in principle, people enjoy seeing and being seen by others (Rutledge \& Albert, 1985). Public space also provides meaning for the community, and access to visit it, as well as allow them to participate and use it (Moudon, 1987). Public space also teaches people to live with others, as they need to respect the norms and keep from distracting others although having the liberty to do any activity they want (Moudon \& Anne, 1987).

\section{The Activities Of City Park Visitors In Bandung}

Currently, Bandung has 604 parks, some of them have more advantages and special trait in the facilities. The visitors' activities in using the wifi facilities in the four parks observed can be seen in Figure 1.

Figure 1. Visitors' Activities in Four City Parks in Bandung

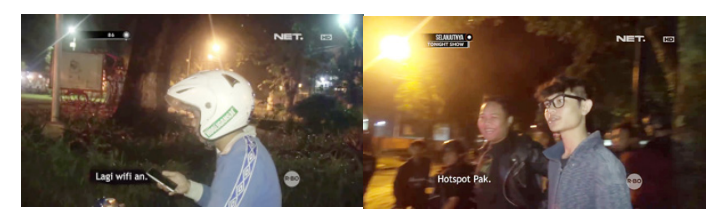

Visitors' activities at Taman Lansia (Elderly Park); enjoying full speed free in the middle of the night.

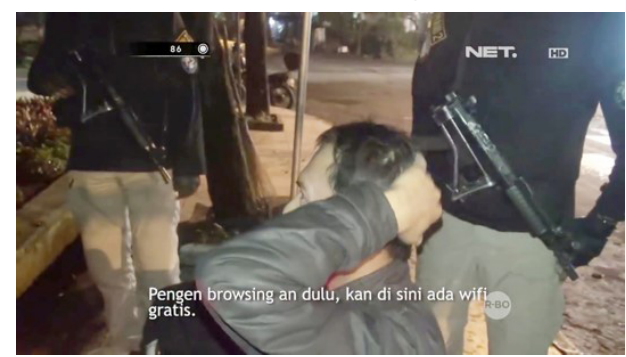

Visitors' activities at Superhero Park; asleep waiting for a download of documents and games to complete.

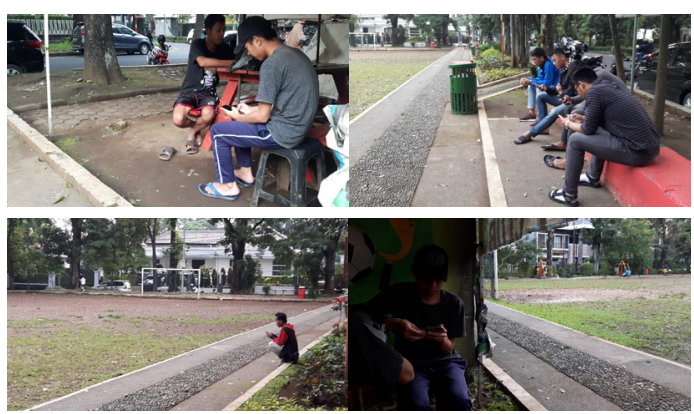

Visitors' activities at Fitness Park; enjoying the park's free wifi facility.

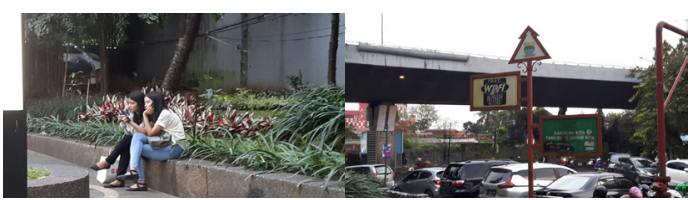

Visitors' activities at Dago Park; looking for a comfortable place for browsing online on the smartphone.

Based on the interview, most visitors agreed that the main reason of visiting the city parks is no longer for real social engagement purposes, but more about other interests, as detailed in the table below. 
Table 1. Main Reasons to Visit the Four City Parks in Bandung

\begin{tabular}{|c|c|c|c|c|}
\hline \multirow{2}{*}{\multicolumn{2}{|c|}{$\begin{array}{l}\text { Location and } \\
\text { Respondent }\end{array}$}} & \multicolumn{3}{|c|}{ Reasons for Visiting City Parks } \\
\hline & & Socialize & Use the wifi & Relax \\
\hline \multirow[t]{6}{*}{1} & Respondent 1 & $\sqrt{ }$ & $\sqrt{ }$ & \\
\hline & Respondent 2 & & $\sqrt{ }$ & \\
\hline & Respondent 3 & & $\sqrt{ }$ & \\
\hline & Respondent 4 & $\sqrt{ }$ & & $\sqrt{ }$ \\
\hline & Respondent 5 & $\sqrt{ }$ & $\sqrt{ }$ & \\
\hline & Respondent 6 & $\sqrt{ }$ & $\sqrt{ }$ & $\sqrt{ }$ \\
\hline 2 & Respondent 1 & & $\sqrt{ }$ & $\sqrt{ }$ \\
\hline & Respondent 2 & $\sqrt{ }$ & $\sqrt{ }$ & $\sqrt{ }$ \\
\hline & Respondent 3 & & $\sqrt{ }$ & \\
\hline & Respondent 4 & & $\sqrt{ }$ & \\
\hline & Respondent 5 & & $\sqrt{ }$ & \\
\hline & Respondent 6 & $\sqrt{ }$ & $\sqrt{ }$ & \\
\hline 3 & Respondent 1 & $\sqrt{ }$ & & \\
\hline 3 & Respondent 2 & & $\sqrt{ }$ & \\
\hline & Respondent 3 & & $\sqrt{ }$ & $\sqrt{ }$ \\
\hline & Respondent 4 & & $\sqrt{ }$ & \\
\hline & Respondent 5 & $\sqrt{ }$ & $\sqrt{ }$ & \\
\hline 4 & Respondent 1 & & $\sqrt{ }$ & $\sqrt{ }$ \\
\hline & Respondent 2 & & $\sqrt{ }$ & $\sqrt{ }$ \\
\hline & Respondent 3 & $\sqrt{ }$ & $\sqrt{ }$ & \\
\hline & Respondent 4 & & $\sqrt{ }$ & $\sqrt{ }$ \\
\hline & Respondent 5 & & $\sqrt{ }$ & $\sqrt{ }$ \\
\hline & Respondent 6 & & $\sqrt{ }$ & $\sqrt{ }$ \\
\hline \multicolumn{5}{|c|}{ Note: } \\
\hline \multicolumn{5}{|c|}{ Location 1: Superhero Park } \\
\hline \multicolumn{5}{|c|}{ Location 2: Lansia Park } \\
\hline \multicolumn{5}{|c|}{ Location 3: Fitness Park } \\
\hline & cation 4: Dago P & & & \\
\hline
\end{tabular}

Indirectly, the activities done in the park will affect the shape and design of the park. This is influenced by the human dimension of open public space, which is the needs of public space for social and psychological conveniences, relaxation, passive activities, active activities, and new experience that is different between visitors. This also relates to the rights, meaning and relationship expected by the visitors when doing activities in the park (Framesthi \& Hindersah, 1993).

According to the type, visitor activities can be grouped into two, namely mobile and immobile. In general, visitors' activities involve strolling, refreshing, exercising, enjoying meals, reading, and having a chat/discussion/laugh.

Based on the field data on 4 city parks in Bandung as detailed in Table 1, it is clearly revealed that visitors not only go to the parks to socialize as the free wireless internet facilities become their main reason. This represents city parks as public space for mobile and immobile activities; lately the latter is more dominant because of the wifi facility provided, resulting in passive activity as the form of human dimension.

\section{Virtual Space At Bandung City Parks}

Virtual world is a dynamic and fixed environment, where an individual may find another individual and interact with each other (Schroeder, 2008).

In the popular understanding, the word "virtual" is associated with anything online. The virtual environment experienced by people from time to time in a great number of populations with others for social interaction. This is why online social space in the internet, even online game, is considered to be a virtual environment, with a third virtual space to socialize (Schroeder, 2008; Steinkuehler \& Williams, 2006). Virtual space that is resulted from visitors' activities in Bandung city parks are in accordance with the form of human interaction depicted in Figure 2. Interaction and one-way, two-way, and multiple-way communications still occur, but all takes place in the virtual world.

Schroeder (2006) defines virtual environment as a computer interface that allows or even forces the users to be present in an environment outside of their reality. It focuses on sensoric experience, in which one experiences a place or space without having to be physically present in that place or space and becomes completely immersed and interact with others in the environment. Virtual environment with multiuser also serves as a collaborative/ social space in the system environment due to the human interaction within the system 
(Schroeder, 2006). In the context of 4 city parks in Bandung, the physical presence of visitors in the park is only concerned with the park as a connecting facility to the virtual communication needs of the people. This means that the activity is not specific to the city parks only, but also other places with similar facilities that can help the users to connect to the virtual world.

Figure 2. Human Interaction Pattern in Virtual Space (Renaningtyas, 2013)

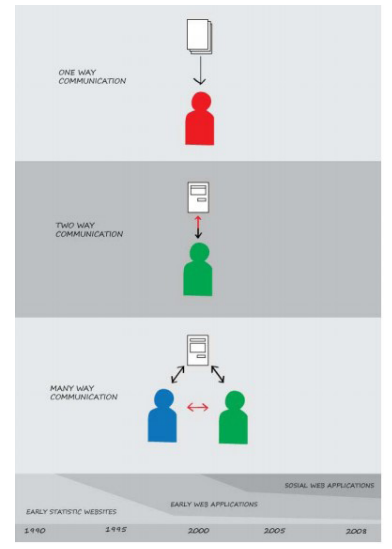

Schroeder (2006) defines virtual environment as a computer interface that allows or even forces the users to be present in an environment outside of their reality. It focuses on sensoric experience, in which one experiences a place or space without having to be physically present in that place or space and becomes completely immersed and interact with others in the environment. Virtual environment with multiuser also serves as a collaborative/ social space in the system environment due to the human interaction within the system (Schroeder, 2006). In the context of 4 city parks in Bandung, the physical presence of visitors in the park is only concerned with the park as a connecting facility to the virtual communication needs of the people. This means that the activity is not specific to the city parks only, but also other places with similar facilities that can help the users to connect to the virtual world.

\section{Degradation And Visual Space}

Technology brings humans into a new world, in which virtual objects are understood as reality. The virtual world makes humans get carried away in it and interrupted from their space of reality, as seen in Figure 3.

The addiction to this virtual space occurs because of the ecstasy of the content inside; there is voyeurism: a beauty to satisfy desire: greed; viscerality: becoming one body to the point that one can no longer distinguish the virtual world and reality (Renaningtyas, 2013). According to the observation done in a dominant manner on what the visitors do in the study area, most visitors use smartphones as the connector to the virtual world. Therefore, it is evident that there has been an addiction to the virtual space (Renaningtyas, 2013) caused by the domination of virtual aura (Piliang, 2011) resulted from the multidirection interactions from the use of technology (Heim, 1993) as described in Figure 4.

The reality and virtual spaces immerse and result in an experience of body, mind, and soul in the study area. This experienced is generated by $10 \%$ consciousness and $90 \%$ subconsciousness in the brain. This means that when a person enters the virtual space, there is a subconscious aspect that makes him or her to get carried away inside of it (Westerink, 2009).

Figure 3 . The space of reality and virtual, separated by a screen (Renaningtyas, 2013)

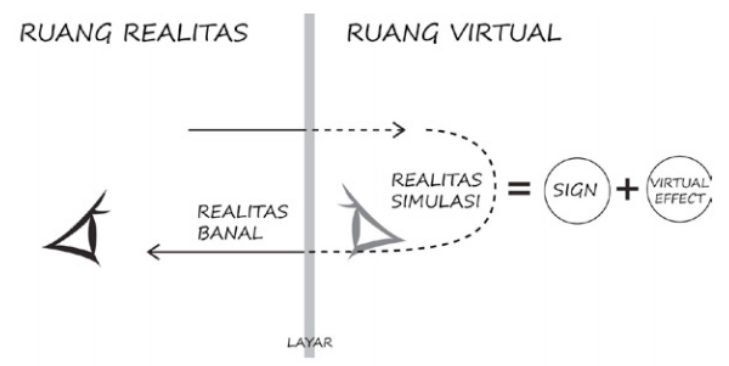

Figure 4. Human entity consisting of body, mind, and soul (Renaningtyas, 2013)

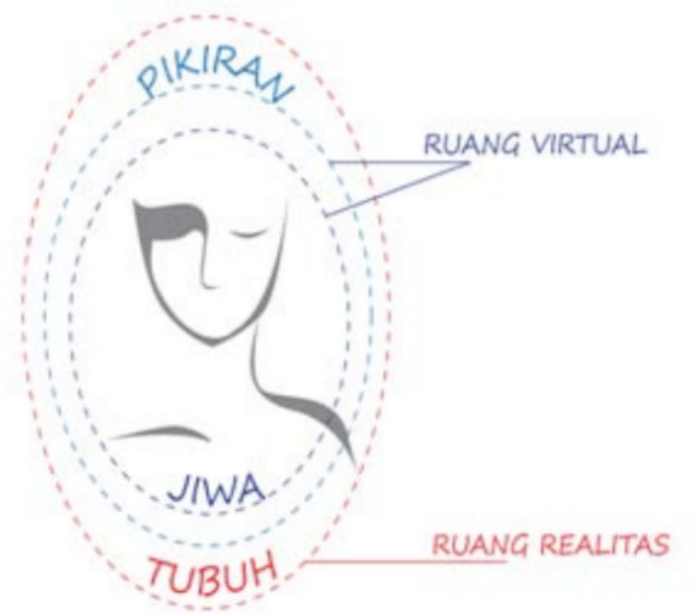


The reality and virtual spaces immerse and result in an experience of body, mind, and soul in the study area. This experienced is generated by $10 \%$ consciousness and $90 \%$ subconsciousness in the brain. This means that when a person enters the virtual space, there is a subconscious aspect that makes him or her to get carried away inside of it (Westerink, 2009).

\section{The Dynamics Of Internet Users}

Technology connecting the world can be seen as either beneficial or harmful to the users and interpersonal relations. By using the internet, we have the ability to disseminate information with a much more rapid speed; this has been related to a number of positive consequences (Ellison, Steinfield, \& Lampe, 2007).

However, because individuals becomes even more dependent on the media for information and entertainment, users might have some difficulties in trying to stop using it. The drive to continue using it may rapidly weaken them as users feel unable to conduct their daily activities because of their inability to cut off from the internet. This impulse control disorder is known as pathological internet use (PIU) or internet addiction (Young \& Rodgers, 1998).

Internet addiction is a state in which the use of internet has become compulsive as users begin to assume that internet dependency is crucial to their psychological well-being, causing them to feel great inconvenience on the absence of internet. This creates a state in which users feels that they need internet in their daily lives (Davis, 2001). If this is what occurs in the Bandung city parks, then what is depicted in the four city parks has been an indication of a systematic symptom as public space users have gotten carried away from the main purpose of city park, that is to get away and refreshed from daily activities (IImiajayati \& Dewi, 2015).

\section{City Parks' Social Function Degradation In The Presence Of Visual Space}

Virtual space and city parks provide a space for urban residents with various responses, both negative and positive, in socializing with others . However, the use of virtual space in the park by the city dwellers has an impact on their tendency to use the facility. Renaningtyas (2013) states that internet users mostly are not able to cut off from the internet and virtual space due to the ecstasy of the content inside, which invites the users to get carried away in it (Ibid, 2013). Virtual space removes the users' sensitivity to the real world, in which the soul should be present in the body. This phenomenon occurs due to the needs of human for technology. There is a tendency among internet users to ignore their surrounding which has the potential to increase a great number of internet users, yet make the social interaction in the park very minimum (Hampton et al., 2010).

This is certainly against the essential values of city parks as social space, as explained by Carr (1992), i,e, a space where people may sit and hang out or read, have a chat with others, or exercise together; a space that provides joy of seeing and being seen by others (responsive space); and a public space that teaches how to live with others (democratic space), psychologically, public space may induce memories of one's experience, or even to alienate one's self and contemplate (meaningful space).

For that reason, the presence of free internet facility in city parks may potentially result in the degradation of the essential function of city parks as social space. Because of the Bandung government's policy to add attractions in the city parks in the form of free internet facility, people are more motivated to go to city parks for the free internet, and not because their need to socialize in a real manner, which should be the intention when visiting a city park. City parks are part of the public and social space that are often overlooked by the urban residents. The shift in the city parks' function due to the change in visitors' activities show the urban community's lack of understanding on the use of city parks to provide a balance in the urban social life.

\section{Social Meaning Shift Of City Parks And The Build-Up Space}

The free wireless internet facility in the city parks has many impacts on the activities done in the parks, for instance having a chat. Now, having a chat is not only limited to two or more visitors of the park, but also just one visitor who chats in the virtual space without engaging in a physical interaction in the place. As a result, the urban residents are moved to go to the park not 
only for one reason, but two reasons. The first is to visit the park as its initial purpose, in which urban residents can interact in a real manner. The second one is park as virtual space, in which social activities can be realized in the virtual world. The free internet wifi has caused a build-up of space that integrate the virtual space into the real world in the form of a park.

The redefinition of city parks' social function at the present is that it does not only serve as public space with social function, but also a place that offers access to virtual social space.

Although city parks offer real social space, it has experienced a meaning shift as the virtual space has taken over the essential function of city parks a social space due to its ability to keep people connected in spite of distance. Therefore, it is recommended that future studies investigate whether city parks are still relevant as a social space; or whether they are no longer needed as the social function has been realized by the meaningless virtual space.

\section{CONCLUSION}

According to the analysis and discussion of the study, the following conclusion is obtained.

- Free internet access increases the park's attraction level and has the potential to increase the number of visitors.

- The presence of free internet facility in the city parks potentially results in the essential function degradation of city parks as social space.

- The use of city parks as social space is often overlooked by the urban residents in using the parks that can provide balance in the urban spaces.

- Although city parks offer real social space, it has experienced a meaning shift as the virtual space has taken over the essential function of city parks a social space due to its ability to keep people connected in spite of distance.

- The urban residents not only have one reason to go to the park, but two; first as city park and second as virtual space. Thus, there is a build-up space that integrate the virtual space into the real world in the form of a park.

- The redefinition of city parks' social function at the present is that it does not only serve as public space with social function, but also a place that offers access to virtual social space.

\section{REFERENCES}

American Planning Association (APA). (2017). City Park Forum Briefing Papers. How Cities Use Parks for...

Anindita, Y. A., \& Suwandono, D. (2015). Perilaku Pengguna Ruang Terbuka Publik Terkait Ketersediaan Akses Internet Pada Taman Lansia Kota Bandung. Ruang, 1(4), 301-310.

Beqaj, B. (2016). Public Space, public interest and challenges of urban transformation. IFAC-PapersOnLine, 49(29), 320-324. https://doi.org/10.1016/j.ifacol.2016.11.087

Carr, Stephen, Leanne, G., Rivlin, Francis, M., \& Stone, A. M. (1992). Public Space (1st ed.). Cambridge: Cambridge University Press.

Davis, R. A. (2001). A cognitive-behavioral model of pathological Internet use. Computers in Human Behavior, 17, 187195.

Ellison, N. B., Steinfield, C., \& Lampe, C. (2007). The Benefits of Facebook "Friends:" Social Capital and College Students' Use of Online Social Network Sites. Journal of Computer-Mediated Communication, 12, 1143-1168. https://doi.org/10.1111/j.10836101.2007.00367.x

Framesthi, D. B., \& Hindersah, H. (1993). Hubugan Antara Aktivitas Pengunjung, 10(1), 1-14.

Gallion, A. B., \& Eisner, S. (1994). Pengantar Perencanaan Kota-Kota: Desain Dan Perencanaan Kota. (Sisongko, Ed.) (5th ed.). Jakarta: Erlangga.

Hampton, B. K. N., Livio, O., Trachtenberg, C., \& Mcewen, R. (2010). The Social Life of Wireless Urban Spaces, 9(4), 1-8.

Heim, M. (1993). The Metaphysics of Virtual Reality (1st ed.). New York: Oxford University Pres.

IImiajayati, F., \& Intan Kusumo Dewi, D. (2015). Persepsi Pengguna Taman Tematik Kota Bandung Terhadap Aksesibilitas Dan Pemanfaatannya. Ruang, 1(1), 21-30. https://doi.org/HTTP://DX.DOI. ORG/10.14710/RUANG.1.4.21-30

Laurie, M. (1986). Arsitektur Pertamanan (1st ed.). Bandung: Intermatra.

Levitz, D. (2014). The Role of Parks in Shaping Successful Cities.

Moudon, \& Anne, V. (1987). Public Street for Public Use (1st ed.). New York: Van 
Nostrand Reinhold Company.

Piliang, Y. A. (2011). Ekonomi Virtual dan Masyarakat Cyber:Menuju Milenium Ketiga. Dunia yang Dilipat (pp. 110-114). Bandung: Jalasutra.

PU, K. Pedoman Penyediaan dan Pemanfaatan Ruang Terbuka non Hijau di Wilayah Kota/ Kawasan Perkotaan, Pub. L. No. 12/ PRT/M/2009 (2009). Indonesia.

Ramlee, M., Omar, D., Mohd Yunus, R., \& Samadi, Z. (2015). Revitalization of Urban Public Spaces: An overview. Social and Behavioral Sciences, 201, 360-367. https:// doi.org/10.1016/j.sbspro.2015.08.187

Rapoport, A. (1977). Human Aspect of Urban Form (1st ed.). New York: Pergamon Press.

Renaningtyas, L. (2013). Ruang Virtual dan Ruang Realitas. Jurnal Desain Komunikasi Visual, 3.

Rubenstein, H. M. (1992). Pedestrian Malls, Streetscapes, and Urban Spaces (1st ed.). Canada: John Wiley \& Sons, Inc.

Rutledge, \& Albert, J. (1985). A Visual Approach to Park Design. Canada: John Wiley \& Sons, Inc.

Schroeder, R. (2006). Being There and the Future of Connected Presence. Presence: Journal of Teleoperators and Virtual Environments, 15(4), 438-454.

Schroeder, R. (2008). Defining Virtual Worlds and Virtual Environments. Journal of Virtual Worlds Research, 1(1), 1-3. https:// doi.org/10.4101/jvwr.v1i1.294

Steinkuehler, C., \& Williams, D. (2006). Where Everybody Knows Your (Screen) Name: Online Games as "Third Places." Journal of Computer-Mediated Communication, 11(4).

Westerink, H. (2009). A Dark Trace: Sigmund Freud on the Sence of Guilt. Leuven: Leuven University Press.

Young, K. S., \& Rodgers, R. C. (1998). The Relationship Between Depression and Internet Addiction, 1(1), 25-28. 